\title{
The PPAR $\gamma$ ligand rosiglitazone influences triacylglycerol metabolism in non- obese males, without increasing the transcriptional activity of PPAR $\gamma$ in the subcutaneous adipose tissue
}

\author{
Annemiek M. C. P. Joosen ${ }^{1} \dagger \dagger$, Arjen H. F. Bakker ${ }^{2}$, Sander Kersten ${ }^{3}$ and Klaas R. Westerterp ${ }^{1}$ \\ ${ }^{1}$ Department of Human Biology, Maastricht University, P.O. Box 616, 6200 MD Maastricht, The Netherlands \\ ${ }^{2}$ Department of Molecular Genetics, Maastricht University, P.O. Box 616, 6200 MD Maastricht, The Netherlands \\ ${ }^{3}$ Division of Human Nutrition, Wageningen University, P.O. Box 8129, 6700 EV Wageningen, The Netherlands
}

(Received 14 March 2007 - Revised 11 July 2007 - Accepted 16 July 2007)

PPAR $\gamma$ is obligatory for fat mass generation and is thought to determine the amount of TAG stored per fat cell. We investigated whether ligand availability for PPAR $\gamma$ is rate limiting in fat mass generation and substrate metabolism. Twenty healthy men (20-29 years) were randomly assigned to receive the PPAR $\gamma$ ligand rosiglitazone (RSG) $(8 \mathrm{mg} / \mathrm{d})(n 10)$ or a placebo $(n 10)$ during a stay of $7 \mathrm{~d}$ in a respiration chamber. Food intake was ad libitum, resulting in positive energy balances of $32.2 \mathrm{MJ}$ (placebo) and $44.7 \mathrm{MJ}$ (RSG). Fat cell size and expression of PPAR $\gamma$, adipocyte fatty acid-binding protein (aP2), adipsin, adiponectin and fasting-induced adipose factor (FIAF) were determined in subcutaneous abdominal fat biopsies. The total amount of fat stored and the amount of TAG per fat cell were not different between groups. For the entire group, fat cell size was decreased after overeating $(P=0 \cdot 02)$. FIAF mRNA levels were decreased after overeating in the RSG group $(P=0.01)$, with a trend towards a decrease in the placebo group. Unexpectedly, RSG treatment did not influence the expression levels of PPAR $\gamma$ and of the PPAR $\gamma$ responsive genes aP2, adiponectin and adipsin. In addition, RSG resulted in a larger increase in plasma TAG during overeating than placebo treatment. These results suggest that in healthy, non-obese males the PPAR $\gamma$ ligand RSG influences TAG metabolism, independent of its PPAR $\gamma$ transcriptional activity in the subcutaneous adipose tissue.

Ligand: Fat cell size: Adipose tissue: Gene expression: Man

The increasing prevalence of obesity is a major health problem as obesity is associated with chronic diseases, which include type II diabetes and $\mathrm{CVD}^{1}$. An excessive adipose tissue mass, the main feature of obesity, is the result of an energy intake that exceeds energy expenditure for longer periods. Yet the molecular mechanisms contributing to the development of obesity remain ill-defined. Fat mass generation depends on an increased volume of adipocytes (hypertrophy), the recruitment of new adipocytes (hyperplasia), decreased apoptosis of adipocytes or a combination of these processes $^{2}$. Obesity accompanied by metabolic disturbances (including insulin resistance, increased production of NEFA, leptin and $\mathrm{TNF} \alpha$ ) is typically associated with hypertrophy of the fat cells ${ }^{3}$.

PPAR $\gamma$, a member of the nuclear hormone receptor superfamily of transcription factors, is required for adipogenesis, which involves the differentiation of preadipocytes into fat-storing mature adipocytes ${ }^{4}$. PPAR $\gamma$ regulates the expression of numerous genes involved in fat storage, including adipocyte fatty acid-binding protein (aP2), lipoprotein lipase and CD36. In addition, PPAR $\gamma$ is involved in the regulation of insulin sensitivity ${ }^{4,5}$. The importance of PPAR $\gamma$ activity in the regulation of fat mass is emphasized by PPAR $\gamma$ mutations. Dominant-positive PPAR $\gamma$ mutations are associated with severe obesity ${ }^{6}$, while dominant-negative PPAR $\gamma$ mutations are associated with partial lipodystrophy ${ }^{7}$. Activation of DNA transcription by PPAR $\gamma$ requires the binding of a ligand, as well as the presence of several transcriptional regulators and cofactors ${ }^{8}$. Natural ligands for PPAR $\gamma$ include PUFA and eicosanoids ${ }^{9}$; synthetic ligands include rosiglitazone (RSG), which is widely and effectively used in the treatment of type II diabetes mellitus for its insulin-sensitizing effects ${ }^{10}$. Treatment with RSG and other thiazolidinediones is accompanied by weight gain in rodents ${ }^{11,12}$ and obese, diabetic patients ${ }^{13}$. In rats, this is due to an increased food intake and an increased feed efficiency ${ }^{12}$. However, the molecular and metabolic basis for the weight gain in obese diabetic patients is not completely clear. We recently overfed healthy, non-obese females and our results suggested that the ability to increase PPAR $\gamma$ activity may be involved in the susceptibility to gain weight ${ }^{14}$. As PPAR $\gamma$ activity depends on ligand binding, the availability of ligand might be involved.

Abbreviations: aP2, adipocyte fatty acid-binding protein; FIAF, fasting-induced adipose factor; RSG, rosiglitazone.

* Corresponding author: Annemiek M.C.P. Joosen, fax +44(0)1223 252 765, email amj@mrc-dunn.cam.ac.uk

$\dagger$ Present address: MRC Dunn Human Nutrition Unit, Wellcome Trust/MRC Building, Hills Road, Cambridge CB2 0XY, UK. 
RSG appears to have its main effects on the adipose tissue, as RSG does only improve glucose and insulin levels in lipoatrophic, diabetic mice after fat transplantation ${ }^{15}$. Specifically, RSG seems to affect the subcutaneous adipose tissue as only human subcutaneous, but not visceral, preadipocytes could be differentiated in vitro with $\mathrm{RSG}^{16}$ and RSG increased subcutaneous, but not visceral, white adipose tissue in rats ${ }^{17}$. In vivo, RSG has been shown to increase the expression of PPAR $\gamma$ response genes in type II diabetic patients ${ }^{18}$. We hypothesized that if PPAR $\gamma$ ligand levels are rate limiting in fat mass generation during overeating, RSG supplementation will increase subcutaneous fat storage. To address this question, healthy, non-obese males were exposed to an obesity-promoting environment while receiving either a placebo or RSG and the amount of TAG stored per fat cell, adipose gene expression, hormones involved in fat storage (insulin, leptin) and substrate availability (glucose, TAG) were determined.

\section{Subjects and methods}

\section{Subjects}

The present study was part of a study investigating the effects of the PPAR $\gamma$ ligand RSG on energy balance regulation, which is described previously ${ }^{19}$. Subjects had to be male, between the age of 18 and 40 years, Caucasian, healthy and have a BMI between 20 and $32 \mathrm{~kg} / \mathrm{m}^{2}$. They had to be unrestrained eaters, i.e. no desire to restrain intake, as indicated by scores $\leq 9$ on factor 1 of the Three-Factor Eating Questionnaire, which reflects the extent to which individuals try to cognitively control their food intake ${ }^{20}$. Subjects completed a medical questionnaire before entering the study; only subjects in good health were included. Subjects who followed a dietary regimen with the aim to lose or gain weight within 1 year prior to the study were excluded. The study design required that the subjects were not fully informed about the adipogenic effect of the PPAR $\gamma$ agonist RSG as this could influence self-selected food and energy intake and activity-induced energy expenditure. Therefore, subjects were informed that they would receive either a substance that influences fat metabolism or a non-active substance (placebo) in a double-blind manner (i.e. neither the subject nor the investigator knew what the subject received during the experiment). The study was approved by the Ethics Committee of Maastricht University. All subjects received verbal and written information and signed a written consent form. Twenty men between the age of 20 and 29 years participated in the study. Characteristics of the subjects are shown in Table 1.

\section{Experimental design}

Subjects were studied during a stay in the respiration chamber for 7 consecutive days for energy expenditure measurements calculated from $\mathrm{V}_{\mathrm{O} 2}, \mathrm{CO}_{2}$ production and urinary $\mathrm{N}$ excretion according to the formula of Brouwer ${ }^{21}$. The respiration chamber measures $14 \mathrm{~m}^{3}$ and is furnished with a bed, chair, table, TV, radio, telephone, computer, washbowl and toilet facilities $^{22}$.

Following a double-blind, placebo-controlled design, subjects were randomly assigned to receive either $8 \mathrm{mg} / \mathrm{d}$ RSG (Avandia; GlaxoSmithKline BV, The Netherlands) or placebo
Table 1. Baseline characteristics of the subjects*

(Mean values with their standard errors)

\begin{tabular}{lccccc}
\hline & \multicolumn{2}{c}{ Placebo (n 10) } & & \multicolumn{2}{c}{ RSG (n 10) } \\
\cline { 2 - 3 } \cline { 6 - 7 } & Mean & SE & & Mean & SE \\
\hline Age (years) & 22 & 1 & & 24 & 1 \\
Height (m) & 1.83 & 0.02 & & 1.84 & 0.02 \\
Body weight (kg) & 80.2 & 3.5 & & 85.7 & 3.6 \\
BMl (kg/m ${ }^{2}$ ) & 24.0 & 1.3 & & 25.1 & 0.7 \\
Body fat (\%) & 19.6 & 1.9 & & 20.3 & 2.4 \\
\hline
\end{tabular}

* For details of subjects and procedures, see Subjects and methods. RSG, rosiglitazone.

orally. Drugs were dosed twice daily for the total stay of $7 \mathrm{~d}$ in the respiration chamber. Subjects were asked to eat ad libitum from an excess of food supplied at each mealtime and as snacks to induce a positive energy balance. No exercise protocol was imposed, but sleeping during daytime and strenuous physical activity were not allowed. Subjects were woken up between $08.00-08.30$ hours, they were free to choose their bedtimes in the evening. Body composition was determined by underwater weighing and deuterium dilution (day 1) or by deuterium dilution alone (day 8). On the same days, blood samples and fat biopsies were taken. Fat storage was calculated as the difference between fat intake and fat oxidation.

\section{Dietary intake}

Meals consisting of typically Dutch food items were provided three times per d, breakfast between 08.30-09.00 hours, lunch between 12.30-13.00 hours and dinner between 18.00-18.30 hours. Breakfast and lunch consisted of bread, savoury and sweet condiments, fruit, yoghurt, milk, fruit juice, instant coffee (decaffeinated) and tea. For dinner, subjects could choose between ready prepared potato-, pasta- or rice-based meals with only vegetables or with vegetables plus meat or fish. They were allowed two alcoholic consumptions, white or red wine or beer, per d. A wide variety of snacks was continuously available in the chamber in packages that were replaced every morning. Snacks consisted of savoury items (crisps, nuts), sweet items (chocolate bars, sweets), various biscuits, fruit (apple, orange, banana), instant soup, fruit juice, instant coffee (decaffeinated) and tea. Meals and snacks were supplied in excess to be eaten ad libitum; extra food items were readily available on request. All foods and drinks entering and leaving the respiration chamber were weighed to the nearest gram. Energy content and macronutrient composition of the diets were calculated using the Dutch food composition table $\mathrm{e}^{23}$.

\section{Procedures}

Anthropometry and body composition. Measurements were carried out in the morning after voiding and before breakfast. Body weight and height were measured to the nearest $0.01 \mathrm{~kg}$ and $0.1 \mathrm{~cm}$ respectively. BMI $\left(\mathrm{kg} / \mathrm{m}^{2}\right)$ was calculated as body weight $(\mathrm{kg})$ divided by height $(\mathrm{m})$ squared. Body density was determined by underwater weighing with simultaneous 
measurement of residual lung volume with the He dilution technique. Total body water was determined with deuterium dilution following the Maastricht protocol ${ }^{24}$. Body composition was calculated from body density and total body water using the three-compartment model of Siri ${ }^{25}$.

Blood parameters. After an overnight fast, blood samples were obtained and mixed with citrate to prevent clotting. Plasma was obtained by centrifugation $\left(4^{\circ} \mathrm{C}, 3000 \mathrm{rpm}\right.$, $10 \mathrm{~min}$ ), frozen in liquid $\mathrm{N}$ and stored at $-80^{\circ} \mathrm{C}$ until analysis of concentrations of glucose (hexokinase method, Glucose HK 125 kit; ABX diagnostics, Montpellier, France), insulin (ELISA, Mercodia, Uppsala, Sweden), leptin (double-antibody RIA, human leptin specific RIA kit, Linco Research Inc., St Charles, USA), TAG (Triglycerides liquicolor kit; Instruchemie, Delfzijl, The Netherlands), NEFA (Wako NEFA C-kit, Wako Chemicals, Neuss, Germany) and HDL-cholesterol (HDL cholesterol liquicolor kit; Instruchemie).

Adipose tissue and RNA isolation. Abdominal subcutaneous fat biopsies (approximately $500 \mathrm{mg}$ ) were obtained by needle liposuction under local anaesthesia (lidocain $2 \%$, AstraZeneca BV, Nederland) after an overnight fast. The tissue was immediately washed in cold PBS and cut into pieces with a scalpel. Then, tissue for mRNA analysis was immediately homogenized in $1 \mathrm{ml}$ Trizol (Invitrogen Life Technologies, Carlsbad, CA, USA) in a mini-beadbeater (Biospec Products, Bartlesville, OK, USA), frozen in liquid $\mathrm{N}$ and stored at $-80^{\circ} \mathrm{C}$ until RNA extraction. Adipocytes were isolated from the remaining fresh tissue as described before $^{26}$. Briefly, the pieces of fat tissue were digested in $5 \mathrm{ml}$ Dulbecco's modified Eagle's medium (DMEM/F12; Invitrogen Life Technologies) containing $4 \%$ bovine serum albumin (Sigma-Aldrich Co, St Louis, MO, USA) and $2 \mathrm{mg} / \mathrm{ml}$ collagenase II (Sigma) in an incubator $\left(37^{\circ} \mathrm{C}, 5 \% \mathrm{CO}_{2}\right)$ on a shaking platform $(200 \mathrm{rpm})$ for $120 \mathrm{~min}$. The digest was transferred to a $5 \mathrm{ml}$ syringe and gently pressed over a $500 \mu \mathrm{m}$ sterile disposable filter (Schleicher \& Schuell MicroScience, Dassel, Germany). The syringe was rinsed with $5 \mathrm{ml}$ DMEM/F12 containing $4 \%$ bovine serum albumin, which was added to the digest. After centrifugation $(1000 \mathrm{rpm}$, $1 \mathrm{~min}$ ), the layer of adipocytes floating on top was removed, frozen in liquid $\mathrm{N}$ and stored at $-80^{\circ} \mathrm{C}$ until analysis of cell size by means of TAG and DNA content.

Total RNA was isolated using the method of Chomczynski and $\mathrm{Sacchi}^{27}$ and $10 \mu \mathrm{g}$ glycogen (Roche Diagnostics GmbH, Mannheim, Germany) was added to each sample. Extracted RNA was quantified and assessed for purity using the NanoDrop (NanoDrop Technologies, Wilmington, DE, USA) and gel electrophoresis (Agilent Technologies, The Netherlands).

Quantification of mRNA expression by real-time RT-PCR. cDNA synthesis and PCR reactions were performed as described previously ${ }^{14}$. The primer sequences were as follows: PPAR $\gamma$ forward $5^{\prime}$-TCCATGCTGTTATGGGTGAA- $3^{\prime}$, reverse $5^{\prime}$-TCAAAGGAGTGGGAGTGGTC-3'; aP2 forward 5'-GCATTCCACCACCAGTTTATC-3', reverse 5'-CAGGAAAGTCAAGAGCACCAT- $3^{\prime}$; fasting-induced adipose factor (FIAF) forward 5'- CACAGCCTGCAGACACAACTC-3', reverse $5^{\prime}$-GGAGGCCAAACTGGCTTTGC-3'; adipsin forward 5'- TAGCGCGACTCCATCTCTACAA- ${ }^{\prime}$, reverse $5^{\prime}$ GCCTCCTGAGTAGCTGGAACT-3'; adiponectin forward $5^{\prime}$-TATCCCCAACATGCCCATTCG-3', reverse $5^{\prime}$-TGGTAGGCAAAGTAGTACAGCC-3'; 36B4 forward 5'- CGGGAA-
GGCTGTGGTGCTG-3' ${ }^{\prime}$, reverse 5'-GTGAACACAAAGCCCACATTCC-3'; $\beta$-actin forward $5^{\prime}$-AGAAAATCT-GGCACCACACC- $3^{\prime}$, reverse 5'-AGAGGCGTACAGGGATAGCA$3^{\prime}$. For target and housekeeping genes, standard curves were created from a specific PCR product ${ }^{14}$. To account for differences in RNA loading, target mRNA was expressed relative to $\beta$-actin and relative to 36B4 mRNA. As both housekeeping genes gave the same normalized quantities, target mRNA levels are presented after normalization to $\beta$-actin.

For determination of TAG and DNA in adipocytes, about $40 \mathrm{mg}$ adipocytes was incubated in a volume of $160 \mu \mathrm{l}$ containing $0.1 \mathrm{M}-\mathrm{NaCl}, 0.02 \mathrm{M}$-Tris $\mathrm{pH} 7.4,0.01 \mathrm{M}$-EDTA $\mathrm{pH}$ $7.5,100 \mu \mathrm{g} / \mathrm{ml}$ proteinase $\mathrm{K}$ and $0.05 \%$ Triton $\mathrm{X}-100$ for $60 \mathrm{~min}$ at $65^{\circ} \mathrm{C}$, followed by $10 \mathrm{~min}$ at $95^{\circ} \mathrm{C}$. Of this solution, $10 \mu \mathrm{l}$ was $100 \times$ diluted before determination of TAG (GPOtrinder 337; Sigma). For DNA determination, the remaining solution was mixed with SDS, RNase A and proteinase $\mathrm{K}$ to make final concentrations of $0.5 \%, 20 \mu \mathrm{g} / \mathrm{ml}$ and $100 \mu \mathrm{g} / \mathrm{ml}$ respectively. After an overnight incubation at $37^{\circ} \mathrm{C}$, DNA was precipitated using ethanol precipitation and a high-salt solution (Kac), rinsed with $70 \%$ ethanol and resuspended in $20 \mu \mathrm{l} \mathrm{H}_{2} \mathrm{O}$. DNA was quantified and assessed for purity using the NanoDrop (NanoDrop Technologies). The mean adipocyte cell size was calculated as $\mu \mathrm{g}$ TAG/cell (mean DNA content per cell is $6 \mathrm{pg}$ ).

\section{Statistical analysis}

Results are presented as means with their standard errors or as median (inter-quartile range). Measurements on the morning of day 1 before entering the respiration chamber are referred to as baseline; measurements on the morning of day 8 after the 7-d respiration chamber stay are referred to as overeating. Effects of overeating within groups were analysed with Student's paired $t$ test (two-sided) or Wilcoxon's paired signed rank test (two-sided) where appropriate. Effects of RSG treatment (between-group effects) were analysed with the MannWhitney $U$-test (two-sided). Significance of correlations was tested with the Spearman rank correlation $\left(r_{\mathrm{S}}\right) . P<0.05$ was considered statistically significant. SPSS 11 for Macintosh (SPSS Inc., Chicago, IL, USA) was used for the analysis.

\section{Results}

\section{Obesity-promoting environment}

For both groups, energy intake (placebo 15.9 (SE 0.9) MJ/d $v$. RSG 18.9 (SE 1.2) $\mathrm{MJ} / \mathrm{d}, P=0.06$ ) was higher than energy expenditure (placebo 11.3 (SE 0.3) MJ/d $v$. RSG 12.5 (SE 0.5) $\mathrm{MJ} / \mathrm{d}, P=0.09)$. By the end of day 7 , the cumulative energy balances were 32.2 (SE 5.1) MJ and 44.7 (SE 6.9) MJ for the placebo and the RSG groups respectively, which was not statistically significant different due to the high inter-individual variation in both groups $(P=0 \cdot 16)$. Body weight increased by $1.39(\mathrm{SE} 0.37) \mathrm{kg}(P<0.01)$ in the placebo group and by 2.54 (SE 0.53$) \mathrm{kg}(P=0.001)$ in the $\mathrm{RSG}$ group. Changes in body weight did not differ significantly between treatments $(P=0.09)$. However, body weight change on RSG was accompanied with an increase in total body water of 1.6 (SE 0.6) litres $(P<0.05)$, whereas total body water did not 
significantly change in the placebo group $(-0 \cdot 2$ (SE 0.7) litres, $P=0.79$ ).

\section{Rosiglitazone causes elevated TAG levels}

In the placebo group, plasma glucose and NEFA were decreased and TAG was increased after overeating, other parameters did not change significantly (Table 2 ). In the RSG group, plasma insulin and TAG were increased and NEFA decreased after overeating; plasma glucose, leptin and HDL-cholesterol did not change significantly. RSG affected changes in plasma glucose $(P=0.02)$ and TAG $(P=0.03)$, but not in plasma NEFA $(P=0.94)$, insulin $(P=0 \cdot 07)$, leptin $(P=0.15)$ and HDL-cholesterol $(P=0 \cdot 97)$. The difference in baseline insulin levels between groups was not statistically significant $(P=0 \cdot 11)$.

\section{Rosiglitazone has no effect on PPAR $\gamma$ transcriptional activity} in subcutaneous adipose tissue

The measured mRNA levels represent PPAR $\gamma$ response genes involved in adipogenesis, lipogenesis and lipolysis, i.e. PPAR $\gamma$, aP2, adipsin, adiponectin and FIAF (Table 3). In the RSG group, FIAF mRNA levels were significantly decreased after overeating (median fold change 0.30, $P=0 \cdot 01$ ), with a trend towards a decrease in the placebo group. However, transcript levels were not statistically significant affected by RSG treatment.

In both groups, there were strong correlations between PPAR $\gamma$ and aP2 mRNA at baseline, after overeating and between changes in expression $\left(r_{\mathrm{S}} 0.83-0.97, P<0 \cdot 01\right)$, indicating that PPAR $\gamma$ mRNA levels are related to PPAR $\gamma$ activity. There were no significant correlations between changes in PPAR $y$ or aP2 mRNA levels and fat storage. Changes in adiponectin mRNA levels were positively correlated with changes in PPAR $\gamma$ or aP2 mRNA levels in both groups $\left(r_{\mathrm{S}} 0.64-0.93, P<0.05\right)$.

\section{Rosiglitazone does not affect fat storage strategy}

The median fat cell size decreased with $50 \%$ in both the placebo and the RSG groups, but this change was not statistically significant ( $P=0.11$ and 0.08 respectively; Table 4 and Fig. 1). There was no statistically significant difference in changes in fat cell size between treatments $(P=0.40)$; for the entire group, fat cell size was decreased after overeating $(P=0.02)$. These changes were accompanied by a, not statistically significant, increase in DNA content $(P=0.77$ placebo; $P=0.14$ RSG). There were no differences in gene expression or plasma parameters between subjects who showed fat cell hypertrophy or hyperplasia after overeating for both groups.

\section{Discussion}

PPAR $\gamma$ is the key regulator of adipose gene expression, whose activity depends on transcriptional regulators and cofactors as well as on ligand availability ${ }^{8}$. To study whether the availability of PPAR $\gamma$ ligand is rate limiting in fat mass generation, we studied the effects of RSG supplementation on several PPAR $\gamma$-dependent processes. The results indicate that ligand availability is of minor importance in subcutaneous fat mass generation.

In both the placebo and RSG groups, PPARy and aP2 mRNA levels were correlated, which indicates activity of PPAR $\gamma$ as aP2 is primarily a PPAR $\gamma$ response gene ${ }^{28,29}$. However, aP2 gene expression was not different between treatments, suggesting that PPAR $\gamma$ ligand availability is not rate limiting for PPAR $\gamma$ activity in subcutaneous adipose tissue in healthy male subjects. Similar results were shown in type II diabetic patients treated with pioglitazone for 24 weeks ${ }^{30}$. Pioglitazone treatment did not change PPAR $\gamma$ mRNA levels and protein content, but baseline levels were strongly correlated with the expression genes involved in fatty acid metabolism, synthesis and storage (acetyl-CoA synthetase, lipoprotein lipase and fatty acid synthase $)^{30}$. Unfortunately, because of the small fat biopsies, we were not able to determine protein levels.

Adiponectin and adipsin are respectively early and late markers of adipocyte differentiation ${ }^{31,32}$. While plasma adipsin concentrations are increased in obesity and correlate with plasma insulin and TAG, adipsin mRNA in subcutaneous fat tissue decreases with increasing $\mathrm{BMI}^{32}$. In contrast, plasma adiponectin and mRNA expression are decreased in obesity

Table 2. Fasting plasma parameters at baseline and after self-induced overeating for the placebo and rosiglitazone (RSG)-treated groupsł

(Mean values with their standard errors)

\begin{tabular}{|c|c|c|c|c|c|c|c|c|}
\hline & \multicolumn{4}{|c|}{ Placebo $(n 10)$} & \multicolumn{4}{|c|}{$\mathrm{RSG}(n 10)$} \\
\hline & \multicolumn{2}{|c|}{ Baseline } & \multicolumn{2}{|c|}{ Overeating } & \multicolumn{2}{|c|}{ Baseline } & \multicolumn{2}{|c|}{ Overeating } \\
\hline & Mean & SE & Mean & SE & Mean & SE & Mean & SE \\
\hline Glucose $(\mathrm{mmol} / \mathrm{l})$ & $5 \cdot 01$ & 0.09 & $4 \cdot 60^{\star \star}$ & 0.06 & $4 \cdot 84$ & $0 \cdot 10$ & $4.93 \dagger$ & 0.18 \\
\hline Insulin $(\mu \mathrm{U} / \mathrm{ml})$ & $7 \cdot 76$ & 0.63 & $8 \cdot 48$ & 0.51 & 6.02 & 0.83 & $8 \cdot 21+\dagger$ & $1 \cdot 10$ \\
\hline Leptin (ng/ml) & $5 \cdot 36$ & $1 \cdot 14$ & 5.56 & 1.00 & $5 \cdot 64$ & 1.37 & $5 \cdot 30$ & $1 \cdot 36$ \\
\hline TAG $(\mathrm{mmol} / \mathrm{l})$ & 0.59 & 0.04 & $1 \cdot 20^{\star \star}$ & 0.18 & 0.78 & 0.11 & $2 \cdot 47^{\star \star}+$ & 0.70 \\
\hline NEFA (mmol/l) & 0.21 & 0.03 & $0 \cdot 11^{*}$ & 0.02 & 0.23 & 0.02 & $0.13^{\star}$ & 0.03 \\
\hline HDL-cholesterol $(\mathrm{mmol} / \mathrm{l})$ & $1 \cdot 18$ & 0.03 & $1 \cdot 21$ & 0.02 & $1 \cdot 24$ & 0.06 & 1.33 & 0.12 \\
\hline
\end{tabular}

Overeating significantly different from baseline (within-group) using Wilcoxon's paired signed rank test: ${ }^{\star} P<0.05,{ }^{\star \star} P<0.01$, $\dagger \dagger P=0.01$.

Change in time significantly different between the placebo and RSG-treated groups using the Mann-Whitney $U$-test: $\dagger P<0.05$ ¥For details of subjects and procedures, see Subjects and methods. 
Table 3. Median (inter-quartile range; IQR) fold changes in mRNA expression in subcutaneous abdominal adipose tissue after self-induced overeating for the placebo and rosiglitazone (RSG)treated groupsł

\begin{tabular}{lcccccccc}
\hline & \multicolumn{2}{c}{ Placebo $(n$ 9) Fold change } & & \multicolumn{2}{c}{ RSG $(n$ 10) Fold change } & Group effect \\
\cline { 2 - 3 } & Median & IQR & $P$ value $^{*}$ & & Median & IQR & $P$ value $^{*}$ & $P$ value \\
\hline PPAR $\gamma$ & 1.46 & 1.34 & 0.31 & & 1.09 & 1.86 & 0.96 & 1.00 \\
aP2 & 1.35 & 1.63 & 0.52 & & 1.21 & 1.79 & 0.72 & 0.88 \\
Adiponectin & 1.01 & 0.40 & 0.95 & & 0.88 & 0.75 & 0.51 & 0.60 \\
Adipsin & 1.04 & 0.67 & 0.68 & & 0.94 & 0.88 & 0.45 & 0.55 \\
FIAF & 0.63 & 0.65 & 0.14 & & 0.30 & 0.34 & 0.01 & 0.13 \\
\hline
\end{tabular}

*Using Wilcoxon's paired signed rank test within groups.

† Using the Mann-Whitney $U$-test between groups.

¥For details of subjects and procedures, see Subjects and methods.

aP2, adipocyte fatty acid-binding protein; FIAF, fasting-induced adipose factor.

and in insulin-resistant patients, independent of obesity ${ }^{31}$ and can be increased by thiazolidinedione treatment ${ }^{33}$. These observations suggest an impaired fat cell function due to a diabetic state, which is typically associated with fat cell hypertrophy ${ }^{3}$. Indeed, fat cell size was shown to be negatively correlated with adiponectin $\mathrm{mRNA}^{34}$. However, we found no effect of RSG or overeating on adiponectin and adipsin mRNA expression, suggesting that RSG has no short-term, or at least an insignificant short-term, effect on adipose gene expression in healthy, non-obese males.

Interestingly, RSG had a significant effect on TAG metabolism (i.e. tissue clearance and/or endogenous synthesis) above the direct postprandial changes in substrate metabolism, as the increase in fasting plasma TAG concentration after overeating was significantly higher in the RSG group. Although carbohydrate intake was higher in the RSG group $^{19}$, we believe this is not due to differences in nutrientrelated (i.e. fructose) TAG production as fruit intake was not significantly different (data not shown). However, we showed previously that whole-body fat oxidation was more suppressed in the RSG group ${ }^{19}$ indicating that the increase in TAG levels resulted from lowered NEFA oxidation in the muscles while physical activity levels were not significantly different between groups (data not shown). These results are in strong contrast to the effects of RSG on the adipose tissue of diabetic patients ${ }^{35}$. A factor directly related to plasma TAG levels and positively regulated by PPAR $\gamma$ is FIAF, which is primarily produced by the adipose tissue and owes its name to its strong up regulation in adipose tissue and liver during fasting ${ }^{36}$. Prolonged high-fat feeding in mice lowers plasma FIAF levels, but not adipose tissue mRNA, and increases plasma TAG levels probably by inhibiting lipoprotein lipase activity ${ }^{36,37}$. We did not find a statistically significant difference in FIAF mRNA between groups, but as adipose FIAF expression decreased during overeating in the RSG group, with a tendency towards a decrease in the placebo group, FIAF may be involved in the observed effects of RSG on TAG metabolism.

In addition to influencing TAG metabolism, RSG treatment was accompanied by pronounced fluid retention. Recent studies in mice show that PPAR $y$ has a direct role in renal $\mathrm{Na}$ re-absorption, providing a mechanism for RSG-induced fluid retention ${ }^{38,39}$. In addition, RSG increased weight and vascular permeability selectively in adipose tissue, but not in skeletal muscle, in lean, fatty and diabetic fatty Zucker rats, indicating that insulin sensitivity is not essential for RSG to induce fluid retention ${ }^{40}$.

In mice, high PPAR $\gamma$ activity is associated with an increase in fat cell size on a high-fat diet, while low PPAR $\gamma$ activity is associated with an increase in fat cell number ${ }^{41}$. In the present study, fat cell size was decreased after overeating, suggesting that fat was stored in newly recruited fat cells. RSG did not influence this storage strategy.

We can speculate that the fat mass itself might be involved in ligand availability, ligand binding and cofactor recruitment, which might explain why RSG has different effects in nonobese, healthy subjects compared with obese, diabetic patients. Furthermore, despite the absence of increased transcriptional activity of PPAR $\gamma$ in the subcutaneous adipose tissue, the primary target tissue of RSG, RSG induced pronounced changes in

Table 4. TAG and DNA contents of subcutaneous adipocytes at baseline and after self-induced overeating for the placebo and rosiglitazone (RSG)-treated groupst

\begin{tabular}{|c|c|c|c|c|c|c|c|c|}
\hline & \multicolumn{4}{|c|}{ Placebo ( $n 9)$} & \multicolumn{4}{|c|}{$\mathrm{RSG}(n 9)$} \\
\hline & \multicolumn{2}{|c|}{ Baseline } & \multicolumn{2}{|c|}{ Overeating } & \multicolumn{2}{|c|}{ Baseline } & \multicolumn{2}{|c|}{ Overeating } \\
\hline & Median & IQR & Median & IQR & Median & IQR & Median & IQR \\
\hline$\mu \mathrm{g}$ TAG/mg adipocytes & 284.4 & 774.3 & $275 \cdot 9$ & $139 \cdot 1$ & $350 \cdot 7$ & 305.9 & 271.5 & $300 \cdot 1$ \\
\hline ng DNA/mg adipocytes & 4.0 & $6 \cdot 3$ & $7 \cdot 4$ & $6 \cdot 3$ & 4.8 & 3.3 & $7 \cdot 2$ & 11 \\
\hline$\mu \mathrm{g}$ TAG/cell ${ }^{*}$ & 0.43 & 0.54 & 0.22 & 0.28 & 0.44 & 0.85 & 0.23 & 0.22 \\
\hline
\end{tabular}

* Calculated from the mean DNA content per cell; 6 pg.

$\dagger$ For details of subjects and procedures, see Subjects and methods.

IQR, inter-quartile range. 


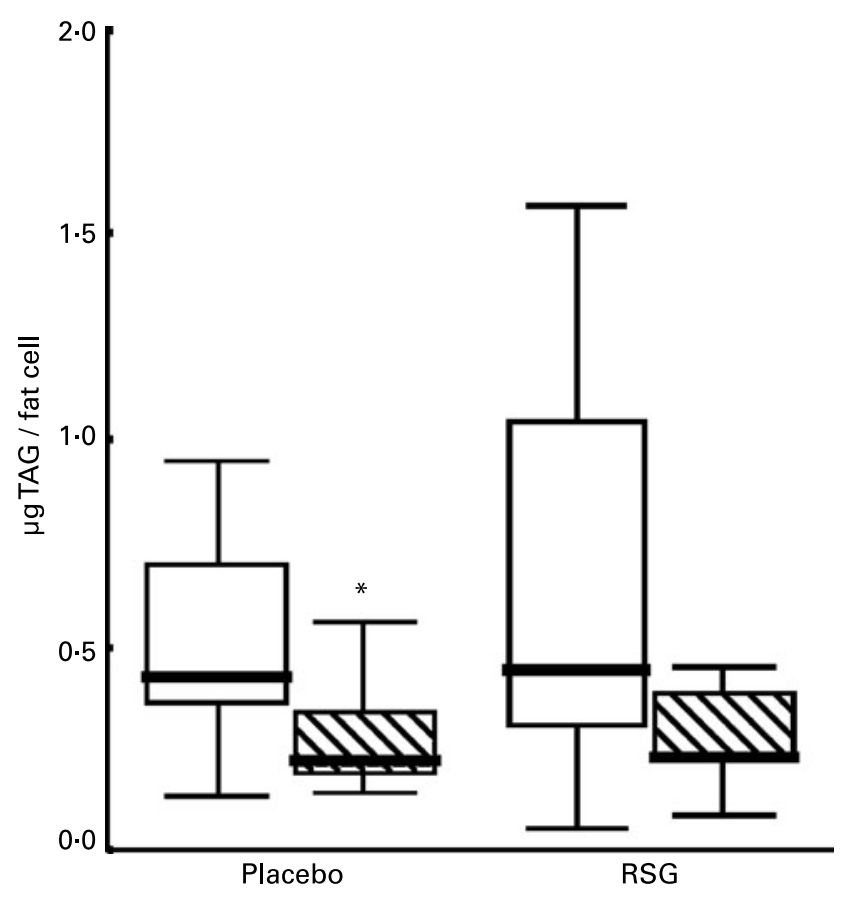

Fig. 1. Boxplot graph of fat cell size in subcutaneous abdominal adipose tissue at baseline $(\square)$ and after self-induced overeating $(\mathbb{\mathbb { Q }}$ ) ( $n 9$ for each treatment due to small fat biopsies in two subjects). Outlier marked with an asterisk. RSG, rosiglitazone. For details of subjects and procedures, see Subjects and methods.

water balance and fat oxidation and tended to increase food intake $^{19}$. Although effects on transcriptional activity in other organs cannot be ruled out, the adipose tissue is widely recognized as the main site of action of PPAR $\gamma$ agonists. In the absence of differences in PPAR $\gamma$ activity between treatments, alternative pathways for RSG may have been involved. In rats, thiazolidinediones acutely activate AMP-activated protein kinase in adipose tissue, and also in skeletal muscle and liver. This effect is most likely independent of PPAR $\gamma$-activated gene transcription $^{42}$. In turn, phosphorylation of PPAR $\gamma$ by AMP-activated protein kinase inhibits its transcriptional activity ${ }^{43}$. However, we can only speculate, as this experiment was not designed to study nontranscriptional effects of RSG. The possibility of alternative pathways and, if any, their relative importance and changes in time need to be investigated in further research.

In conclusion, the present results suggest that in healthy, non-obese males the PPAR $\gamma$ ligand RSG influences TAG metabolism without increasing the transcriptional activity of PPAR $y$ in the subcutaneous adipose tissue.

\section{Acknowledgements}

We thank Maarten Gering for help in data collection and Gabby Hul for obtaining the fat samples. None of the authors had financial or personal conflicts of interest.

\section{References}

1. Silventoinen K, Sans S, Tolonen H, Monterde D, Kuulasmaa K, Kesteloot H \& Tuomilehto J (2004) Trends in obesity and energy supply in the WHO MONICA Project. Int $J$ Obes Relat Metab Disord 28, 710-718.

2. Prins JB \& O'Rahilly S (1997) Regulation of adipose cell number in man. Clinical Science 92, 3-11.

3. Farnier C, Krief S, Blache M, Diot-Dupuy F, Mory G, Ferre P \& Bazin R (2003) Adipocyte functions are modulated by cell size change: potential involvement of an integrin/ERK signalling pathway. Int J Obes Relat Metab Disord 27, 1178-1186.

4. Rosen ED, Sarraf P, Troy AE, Bradwin G, Moore K, Milstone DS, Spiegelman BM \& Mortensen RM (1999) PPAR $\gamma$ is required for the differentiation of adipose tissue in vivo and in vitro. Mol Cell 4, 611-617.

5. Evans RM, Barish GD \& Wang YX (2004) PPARs and the complex journey to obesity. Nat Med 10, 355-361.

6. Ristow M, Muller-Wieland D, Pfeiffer A, Krone W \& Kahn CR (1998) Obesity associated with a mutation in a genetic regulator of adipocyte differentiation. $N$ Engl J Med 339, 953-959.

7. Savage DB, Tan GD, Acerini CL, et al. (2003) Human metabolic syndrome resulting from dominant-negative mutations in the nuclear receptor peroxisome proliferator-activated receptor-gamma. Diabetes 52, 910-917.

8. Miard S \& Fajas L (2005) Atypical transcriptional regulators and cofactors of PPAR $\gamma$. Int J Obes Relat Metab Disord 29, Suppl. 1, S10-S12.

9. Kliewer SA, Sundseth SS, Jones SA, et al. (1997) Fatty acids and eicosanoids regulate gene expression through direct interactions with peroxisome proliferator-activated receptors $\alpha$ and \%. Proc Natl Acad Sci USA 94, 4318-4323.

10. Lehmann JM, Moore LB, Smith-Oliver TA, Wilkison WO, Willson TM \& Kliewer SA (1995) An antidiabetic thiazolidinedione is a high affinity ligand for peroxisome proliferator-activated receptor $\gamma$ (PPAR $\gamma$ ). J Biol Chem 270, 12953-12956.

11. Chaput E, Saladin R, Silvestre M \& Edgar AD (2000) Fenofibrate and rosiglitazone lower serum triglycerides with opposing effects on body weight. Biochem Biophys Res Commun 271, $445-450$.

12. Larsen PJ, Jensen PB, Sorensen RV, Larsen LK, Vrang N, Wulff EM \& Wassermann K (2003) Differential influences of peroxisome proliferator-activated receptors $\gamma$ and $-\alpha$ on food intake and energy homeostasis. Diabetes 52, 2249-2259.

13. Asnani S, Richard BC, Desouza C \& Fonseca V (2003) Is weight loss possible in patients treated with thiazolidinediones? Experience with a low-calorie diet. Curr Med Res Opin 19, 609-613.

14. Joosen AM, Bakker AH, Zorenc AH, Kersten S, Schrauwen P \& Westerterp KR (2006) PPAR $\gamma$ activity in subcutaneous abdominal fat tissue and fat mass gain during short-term overfeeding. Int J Obes (Lond) 30, 302-307.

15. Chao L, Marcus-Samuels B, Mason MM, Moitra J, Vinson C, Arioglu E, Gavrilova O \& Reitman ML (2000) Adipose tissue is required for the antidiabetic, but not for the hypolipidemic, effect of thiazolidinediones. J Clin Invest 106, 1221-1228.

16. Hutley LJ, Newell FM, Joyner JM, Suchting SJ, Herington AC, Cameron DP \& Prins JB (2003) Effects of rosiglitazone and linoleic acid on human preadipocyte differentiation. Eur $J$ Clin Invest 33, 574-581.

17. Berthiaume M, Sell H, Lalonde J, Gelinas Y, Tchernof A, Richard D \& Deshaies Y (2004) Actions of PPARy agonism on adipose tissue remodeling, insulin sensitivity, and lipemia in absence of glucocorticoids. Am J Physiol Regul Integr Comp Physiol 287, R1116-R1123.

18. Tiikkainen M, Hakkinen AM, Korsheninnikova E, Nyman T, Makimattila S \& Yki-Jarvinen H (2004) Effects of rosiglitazone and metformin on liver fat content, hepatic insulin resistance, insulin clearance, and gene expression in adipose tissue in patients with type 2 diabetes. Diabetes 53, 2169-2176. 
19. Joosen AM, Bakker AH, Gering MJ \& Westerterp KR (2006) The effect of the PPAR $\gamma$ ligand rosiglitazone on energy balance regulation. Diabetes Metab Res Rev 22, 204-210.

20. Stunkard AJ \& Messick S (1985) The three-factor eating questionnaire to measure dietary restraint, disinhibition and hunger. J Psychosom Res 29, 71-83.

21. Brouwer E (1957) On simple formulae for calculating the heat expenditure and the quantities of carbohydrate and fat oxidized in metabolism of men and animals, from gaseous exchange (oxygen intake and carbonic acid output) and urine-N. Acta Physiol Pharmacol Neerl 6, 795-802.

22. Schoffelen PF, Westerterp KR, Saris WH \& Ten Hoor F (1997) A dual-respiration chamber system with automated calibration. J Appl Physiol 83, 2064-2072.

23. NEVO Foundation, NEVO table. Dutch Food Composition Table (1996) [in Dutch]. The Netherlands Nutrition Center, The Hague, The Netherlands.

24. Westerterp KR, Wouters L \& Marken Lichtenbelt WDv (1995) The Maastricht protocol for the measurement of body composition and energy expenditure with labeled water. Obes Res 3, 49-57.

25. Siri WE (1993) Body composition from fluid spaces and density: analysis of methods. 1961. Nutrition 9, 480-491, discussion 480, 492.

26. Bakker AH, Van Dielen FM, Greve JW, Adam JA \& Buurman WA (2004) Preadipocyte number in omental and subcutaneous adipose tissue of obese individuals. Obes Res 12, 488-498.

27. Chomczynski P \& Sacchi N (1987) Single-step method of RNA isolation by acid guanidinium thiocyanate-phenol-chloroform extraction. Anal Biochem 162, 156-159.

28. Ross SR, Graves RA, Greenstein A, Platt KA, Shyu HL, Mellovitz B \& Spiegelman BM (1990) A fat-specific enhancer is the primary determinant of gene expression for adipocyte P2 in vivo. Proc Natl Acad Sci U S A 87, 9590-9594.

29. Sen A, Lea-Currie YR, Sujkowska D, Franklin DM, Wilkison WO, Halvorsen YD \& Gimble JM (2001) Adipogenic potential of human adipose derived stromal cells from multiple donors is heterogeneous. J Cell Biochem 81, 312-319.

30. Bogacka I, Xie H, Bray GA \& Smith SR (2004) The effect of pioglitazone on peroxisome proliferator-activated receptor- $\gamma$ target genes related to lipid storage in vivo. Diabetes Care 27, $1660-1667$.

31. Gustafson B, Jack MM, Cushman SW \& Smith U (2003) Adiponectin gene activation by thiazolidinediones requires PPAR $\gamma 2$, but not $\mathrm{C} / \mathrm{EBP} \alpha$-evidence for differential regulation of the aP2 and adiponectin genes. Biochem Biophys Res Commun 308, 933-939.

32. Xia Z \& Cianflone K (2003) Acylation-stimulating protein precursor proteins in adipose tissue in human obesity. Metabolism 52, 1360-1366.
33. Maeda N, Takahashi M, Funahashi T, et al. (2001) PPAR $\gamma$ ligands increase expression and plasma concentrations of adiponectin, an adipose-derived protein. Diabetes 50, 2094-2099.

34. Yang X, Jansson PA, Nagaev I, Jack MM, Carvalho E, Sunnerhagen KS, Cam MC, Cushman SW \& Smith U (2004) Evidence of impaired adipogenesis in insulin resistance. Biochem Biophys Res Commun 317, 1045-1051.

35. Boden G, Homko C, Mozzoli M, Showe LC, Nichols C \& Cheung P (2005) Thiazolidinediones upregulate fatty acid uptake and oxidation in adipose tissue of diabetic patients. Diabetes 54, 880-885.

36. Kersten S, Mandard S, Tan NS, Escher P, Metzger D, Chambon P, Gonzalez FJ, Desvergne B \& Wahli W (2000) Characterization of the fasting-induced adipose factor FIAF, a novel peroxisome proliferator-activated receptor target gene. J Biol Chem 275, 28488-28493.

37. Mandard S, Zandbergen F, Tan NS, et al. (2004) The direct peroxisome proliferator-activated receptor target fasting-induced adipose factor (FIAF/PGAR/ANGPTL4) is present in blood plasma as a truncated protein that is increased by fenofibrate treatment. $J$ Biol Chem 279, 34411-34420.

38. Guan Y, Hao C, Cha DR, et al. (2005) Thiazolidinediones expand body fluid volume through PPAR stimulation of ENaC-mediated renal salt absorption. Nat Med 11, $861-866$.

39. Zhang H, Zhang A, Kohan DE, Nelson RD, Gonzalez FJ \& Yang T (2005) Collecting duct-specific deletion of peroxisome proliferator-activated receptor $\gamma$ blocks thiazolidinedioneinduced fluid retention. Proc Natl Acad Sci U S A 102, 9406-9411.

40. Sotiropoulos KB, Clermont A, Yasuda Y, et al. (2006) Adipose-specific effect of rosiglitazone on vascular permeability and protein kinase $\mathrm{C}$ activation: novel mechanism for PPAR $y$ agonist's effects on edema and weight gain. Faseb J 20, 1203-1205.

41. Kubota N, Terauchi Y, Miki H, et al. (1999) PPAR $\gamma$ mediates high-fat diet-induced adipocyte hypertrophy and insulin resistance. Mol Cell 4, 597-609.

42. LeBrasseur NK, Kelly M, Tsao TS, Farmer SR, Saha AK, Ruderman NB \& Tomas E (2006) Thiazolidinediones can rapidly activate AMP-activated protein kinase in mammalian tissues. Am J Physiol Endocrinol Metab 291, E175-E181.

43. Diradourian C, Girard J \& Pegorier JP (2005) Phosphorylation of PPARs: from molecular characterization to physiological relevance. Biochimie 87, 33-38. 